\title{
Pembentukan Portofolio Optimal dengan Menggunakan Mean Absolute Deviation dan Conditional Mean Variance
}

\author{
Eka Nur Vanti, Epha Diana Supandi \\ Program Studi Matematika, Fakultas Sains dan Teknologi, UIN Sunan Kalijaga, JI. Marsda Adisucipto \\ No. 1 Yogyakarta, Indonesia.
}

Korespondensi; Epha Diana Supandi, Email: epha.supandi@uin-suka.ac.id

\begin{abstract}
Abstrak
Penelitian ini membahas tentang pembentukan portofolio optimal menggunakan model Mean Absolute Deviation (MAD) dan model Conditional Mean Variance (CMV). Pada model MAD risiko portofolio diukur menggunakan rata-rata deviasi standar sehingga portofolio optimal dapat diperoleh dengan menggunakan pemrograman linear. Sedangkan portofolio model CMV, rata-rata return diestimasi menggunakan model Autoregressive (AR) dan risiko (variansi) diestimasi menggunakan model GARCH. Selanjutnya kedua model portofolio diterapkan dalam membentuk portofolio optimal pada saham-saham yang terdaftar dalam Indeks Saham Syariah Indonesia (ISSI) periode 4 Juli 2016 sampai 4 Juli 2018. Kinerja kedua portofolio dianalisis menggunakan indeks Sortino. Hasilnya menunjukan bahwa kinerja portofolio model CMV lebih baik dibandingkan model portofolio MAD.
\end{abstract}

Kata Kunci: Autoregressive; Conditional Mean Variance; GARCH; Indeks Sortino; Mean Absolute Deviation; Portofolio

\begin{abstract}
This study discusses the formation of optimal portfolios using the Mean Absolute Deviation (MAD) model and the Conditional Mean Variance (CMV) model. The MAD portfolio model measures portfolio risk by using average standard deviations so that optimal portfolios solved by using linear programming. Meanwhile the CMV portfolio model, the average return estimated by using the Autoregressive (AR) model and the risk (variance) estimated by using the GARCH model. Furthermore, both portfolio models applied in forming optimal portfolios for stocks listed in the Indonesian Syariah Stock Index (ISSI) for the period 4 July 2016 to 4 July 2018. The performance of both portfolios analyzed by using the Sortino index. The results show that the portfolio performance of the CMV model is better than MAD portfolio model.
\end{abstract}

Keywords: Autoregressive; Conditional Mean Variance; GARCH; Mean Absolute Deviation; Portfolio; Sortino index

\section{Pendahuluan}

Investasi sangat penting dilakukan karena dapat mendorong pertumbuhan ekonomi yang ditandai dengan meningkatnya transaksi jual-beli, simpan-pinjam serta kegiatan ekonomi lainnya. Salah satu strategi dalam berinvestasi adalah dengan membentuk portofolio. Portofolio ditujukan untuk mengurangi risiko investasi dengan cara mendistribusikan dana ke berbagai aset yang berbeda (diversifikasi) [5], [6].

Ada beberapa model portofolio yang dapat dibentuk diantaranya adalah model Mean Absolute Deviation (MAD) serta Conditional Mean Variance (CMV). Kedua model ini adalah pengembangan dari model portofolio Mean Variance yang pertama kali dikenalkan oleh Markowitz [8]. Portofolio Markowitz didasarkan atas pendekatan mean (rata-rata) dan variance (varian), dimana mean merupakan pengukuran tingkat return dan varian merupakan pengukuran tingkat risiko.

Berbeda dengan model Markowitz, risiko portofolio model MAD diukur dengan menggunakan mean absolute deviation sehingga kelebihan dari model ini adalah dapat diselesaikan dengan menggunakan pemrograman linear [7]. 
Portofolio model Conditional Mean Variance digunakan untuk mengatasi masalah autokorelasi antar aset yang mengakibatkan model portofolio menjadi kurang optimal [3]. Untuk mengatasi masalah tersebut maka rata-rata return asset terlebih dahulu diestimasi menggunakan model AR (Autoregressive) dan variansi diestimasi dengan model GARCH (Generalized Autoregressive Conditional Heterokedasticity).

Dalam konteks Islam, investasi merupakan kegiatan yang sangat dianjurkan karena dapat mendorong pertumbuhan ekonomi yang ditandai dengan meningkatnya transaksi jual-beli, simpan-pinjam serta kegiatan ekonomi lainnya. Seperti dalam sebuah riwayat hadits, Nabi Muhammad bersabda, Merugilah hamba dinar, merugilah hamba dirham. (HR. Bukhari). Hadist tersebut mengisyaratkan sebuah perintah agar umat Islam tidak menumpuk kekayaan yang dimiliki. Sebaliknya, mereka diperintah untuk memanfaatkan kekayaan mereka dalam bentuk investasi. Allah SWT juga berfirman dalam QS. At-Taubah: 34, "Dan orang-orang yang menyimpan emas dan perak dan tidak menafkahkannya di jalan Allah, maka beritahukanlah kepada mereka bahwa mereka akan mendapatkan siksaan yang pedih." Dari ayat tersebut dapat disimpulkan bahwa Allah SWT melarang segala usaha penimbunan harta benda dan memerintahkan untuk memanfaatkannya.

Salah satu jenis investasi yaitu investasi pada aset keuangan contohnya adalah saham. Saham merupakan salah satu komoditas keuangan yang sangat populer diperdagangkan di pasar modal. Salah satu indeks saham yang memenuhi kriteria syariah adalah Indeks Saham Syariah Indonesia (ISSI). Hadirnya ISSI diharapkan dapat mempermudah perusahaan sekuritas dalam melahirkan produk investasi syariah. ISSI memuat semua pergerakan saham yang masuk dalam kategori Daftar Efek Syariah (DES). Oleh karena itu, tujuan penelitian ini adalah membentuk portofolio optimal model MAD dan CMV pada saham-saham yang terdaftar di ISSI.

\section{Landasan Teori}

Portofolio merupakan gabungan dari beberapa aset yang dimiliki oleh investor baik berupa aset riil maupun finansial [5], [6]. Misalkan seorang investor menanamkan modalnya pada $n$ asset. Return portofolio adalah:

Dimana,

$$
R_{p}=w_{1} r_{1}+w_{2} r_{2}+\cdots+w_{n} r_{n}=w^{T} r
$$

w : vektor bobot

$R_{p} \quad$ : return portofolio

$r_{i} \quad$ : return asset ke- $i$

$n \quad$ : banyaknya aset

Sedangkan risiko portofolio adalah:

Dimana,

$$
\sigma_{p}^{2}=\sum_{j=1}^{n} \sum_{i=1}^{n} w_{i} w_{j} \sigma_{i j}=w^{T} \Sigma w
$$

$\Sigma \quad$ : matriks variansi kovariansi

$\sigma_{p}^{2} \quad$ : variansi portofolio (risiko portofolio)

Portofolio Model Conditional Mean Variance

Portofolio adalah sekumpulan asset. Portofolio Mean Variance (MV) diperkenalkan oleh Harry M. Markowitz pada tahun 1952 sehingga portofolio tersebut dikenal dengan sebutan Teori Portofolio Markowitz [8]. Secara matematis portofolio model MV dapat dirumuskan sebagai berikut:

$$
\begin{array}{cc}
\text { Fungsi tujuan: } & \min _{w} w^{T} \sum w \\
\text { Fungsi kendala: } & w^{T} \mu=R \\
1_{n} w & =1
\end{array}
$$


Dengan:

$\mu \quad$ : vektor expected return

$R \quad$ : return portofolio yang diinginkan

$1_{n} \quad$ : vector dengan elemen 1

Pada model Mean Variance, rata-rata dan variansi return saham yang dimodelkan tidak boleh terjadi autokorelasi antar data, hal ini mengakibatkan portofolio yang terbentuk menjadi kurang optimal. Oleh karena itu dikembangkannya model Conditional Mean Variance karena dalam menerapkan model yang baik diharuskan adanya autokorelasi antar data.

Dalam model Conditional Mean Variance, rata-rata return diestimasi dengan menggunakan model AR (Autoregressive) dan variansi return saham diestimasi dengan menggunakan model GARCH (Generalized Autoregressive Conditional Heteroscedasticity).

Autoregressive adalah bentuk regresi yang menghubungkan nilai pengamatan $Y_{t}$ dengan nilai-nilai sebelumnya pada selang waktu tertentu [2]. Secara umum, persamaan $\operatorname{AR}(p)$ dapat dituliskan

$$
Y_{t}=\phi_{0}+\phi_{1} Y_{t-1}+\phi_{2} Y_{t-2}+\cdots+\phi_{p} Y_{t-p}+Z_{t}
$$

Diasumsikan $Y_{S}$ dan $Z_{t}$ saling bebas $\forall s<t, \phi_{0}=\mu\left(1-\phi_{1}-\phi_{2}-\cdots-\phi_{p}\right)$ dan $t$ adalah periode waktu.

Model merupakan perkembangan dari model ARCH karena model GARCH dimaksudkan untuk memperbaiki ARCH. Peramalan volatilitas biasanya menggunakan varians $\left(\sigma^{2}\right)$ yang konstan dari waktu ke waktu $(t)$ tetapi volatilitas data time series tidak selalu konstan [3], [4], [10]. Oleh karena itu, kelebihan model GARCH mampu mengkonstankan varians yang berubah-ubah dari waktu ke waktu.

Secara umum model GARCH $(p, q)$ dapat didefinisikan sebagai berikut:

$$
Y_{t}=\beta_{0}+\beta_{1} Y_{t-1}+\alpha_{1} \sigma_{t}^{2}+\varepsilon_{t}
$$

Dengan:

$$
\begin{aligned}
\sigma_{t}^{2} & =\alpha_{0}+\alpha_{1} \varepsilon_{t-1}^{2}+\cdots+\alpha_{p} \varepsilon_{t-p}^{2}+\beta_{1} \sigma_{t-1}^{2}+\cdots+\beta_{q} \sigma_{t-q}^{2} \\
& =\alpha_{0}+\sum_{i=1}^{p} \alpha_{i} \varepsilon_{t-i}^{2}+\sum_{j=1}^{q} \beta_{j} \sigma_{t-j}^{2}
\end{aligned}
$$

Setelah, rata-rata return dan variansi diperoleh dari model AR dan $\mathrm{GARCH}$, maka portofolio optimal model CMV dapat diperoleh melalui persamaan berikut ini:

$$
w=\Sigma^{-1}\left(\left(\frac{b-R c}{b^{2}-a c}\right) \mu+\left(\frac{R b-a}{b^{2}-a c}\right) 1_{n}\right)
$$

Dengan $=\mu^{T} \Sigma \mu ; b=\mu^{T} \Sigma 1_{n}$ dan $c=1^{T} \Sigma 1_{n}$

\section{Portofolio Model Mean Absolute Deviation}

Mean Absolute Deviation (MAD) merupakan model portofolio optimal berbentuk linear programming yang diperkenalkan oleh Konno dan Yamazaki (1991). Model ini merupakan alternatif dari teknik portofolio Markowitz yang berbentuk kuadratik yang dianggap sulit diselesaikan.

Tujuan utama portofolio Mean Absolute Deviation yaitu meminimalkan nilai risiko yang ditanggung investor pada tingkat return tertentu. Nilai risiko dari portofolio Mean Absolute Deviation dihitung dengan menentukan rata-rata nilai mutlak penyimpangan (Mean Absolute Deviation) dari tingkat realized return terhadap expected return. Oleh karena itu, portofolio optimal model MAD dapat diperoleh dengan menyelesaikan persamaan berikut ini: 


$$
\begin{gathered}
\text { Fungsi tujuan: } \min _{w} E\left[\left|\sum_{j=1}^{n} r_{j} w_{j}-E\left(\sum_{j=1}^{n} r_{j} w_{j}\right)\right|\right] \\
\text { Fungsi kendala: } \quad \sum_{j=1}^{n} E\left(r_{j}\right) w_{j}=R \\
\sum_{j=1}^{n} w_{j}=1 \\
0 \leq w_{j} \leq u_{j} \text { dengan } j=1,2, \cdots, n
\end{gathered}
$$

Dengan:

$r_{j} \quad:$ realized return saham ke-j

$E\left(r_{j}\right) \quad$ : expected return saham ke-j

$R \quad$ : tingkat return minimal yang diinginkan oleh investor

$w_{j} \quad$ : besar dana atau bobot yang diinvestasikan pada saham ke-j

$u_{j} \quad$ : maksimal dana yang diinvestasikan pada saham ke-j

\section{Bahan dan Metode}

Data yang digunakan pada studi kasus ini adalah data harga saham harian yang terdaftar dalam Indeks Saham Syariah Indonesia (ISSI) periode 4 Juli 2016 sampai dengan 4 Juli 2018. Saham-saham yang tercatat dalam ISSI dipilih dengan kriteria saham yang selalu konsisten masuk dalam ISSI dan memiliki return terbesar. Data harga saham diambil dari www.yahoofinance.com dimana saham yang terpilih adalah Indofarma (Persero) Tbk (INAF), Mitra Adiperkasa Tbk (MAPI), Semen Baturaja (Persero) Tbk (SMBR) dan Semen Baturaja (Persero) Tbk.

Pembentukan portofolio model MAD dilakukan sebagai berikut:

1. Menghitung realized return dan expected return keempat saham

2. Menentukan return minimal yang diharapkan

3. Menghitung nilai MAD masing-masing saham

4. Menghitung bobot portofolio optimal model MAD

Pembentukan portofoio optimal model Conditional Mean Variance dilakukan dengan bantuan metode AR untuk menduga expected return saham dan metode $\mathrm{GARCH}$ untuk menduga variansi return saham. Langkah-langkahnya adalah

1. Uji stasioner data return. Uji ini dilakukan dengan menggunakan uji akar unit.

2. Uji normalitas data return. Uji ini dilakukan dengan menggunakan uji Jarque-Bera.

3. Estimasi model AR untuk keempat saham

4. Hitung expected return saham

5. Uji efek ARCH. Uji ini untuk mengetahui efek heteroskedastisitas yang dilakukan dengan menggunakan uji ARCH-LM

6. Estimasi model GARCH keempat saham

7. Hitung variansi saham

8. Hitung bobot portofolio optimal model CMV

\section{Hasil dan Pembahasan}

Pada kasus ini, pembentukan portofolio optimal model MAD dan CMV diterapkan pada investasi saham yang terdaftar di ISSI. Saham-saham yang terpilih dalam kasus ini ada empat yaitu Indofarma (Persero) Tbk (INAF), Mitra Adiperkasa Tbk (MAPI), Semen Baturaja (Persero) Tbk (SMBR) dan Semen Baturaja (Persero) Tbk. Pergerakan return keempat saham disajikan pada grafik di bawah ini. 


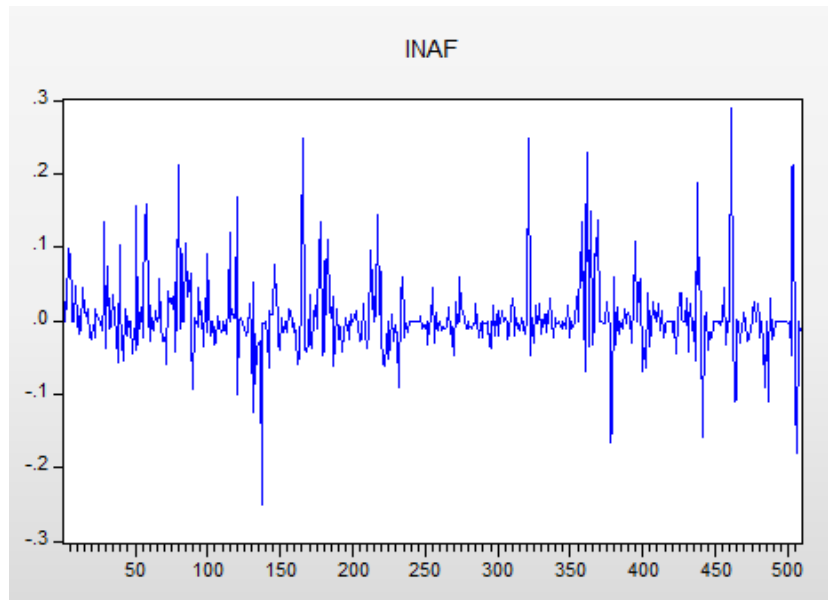

a. Grafik Perkembangan Return Saham INAF

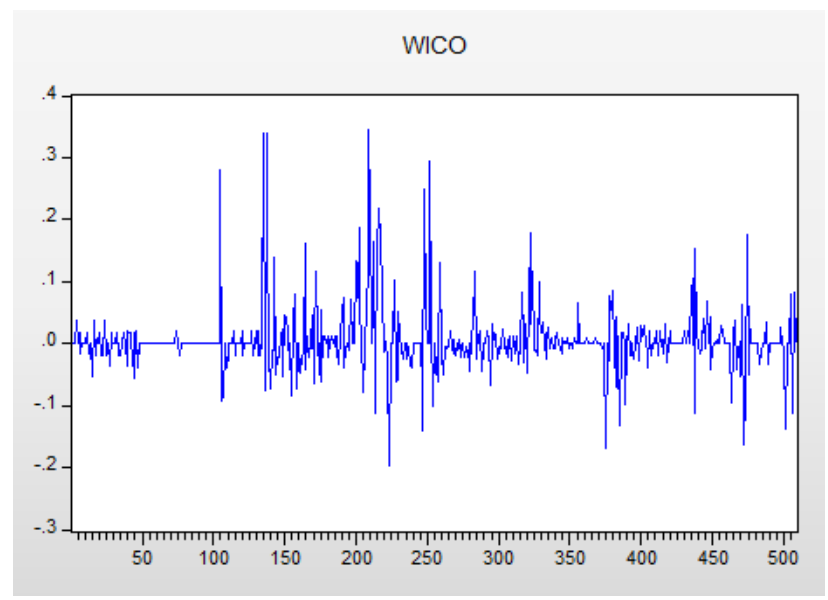

c. Grafik Perkembangan Return Saham WICO

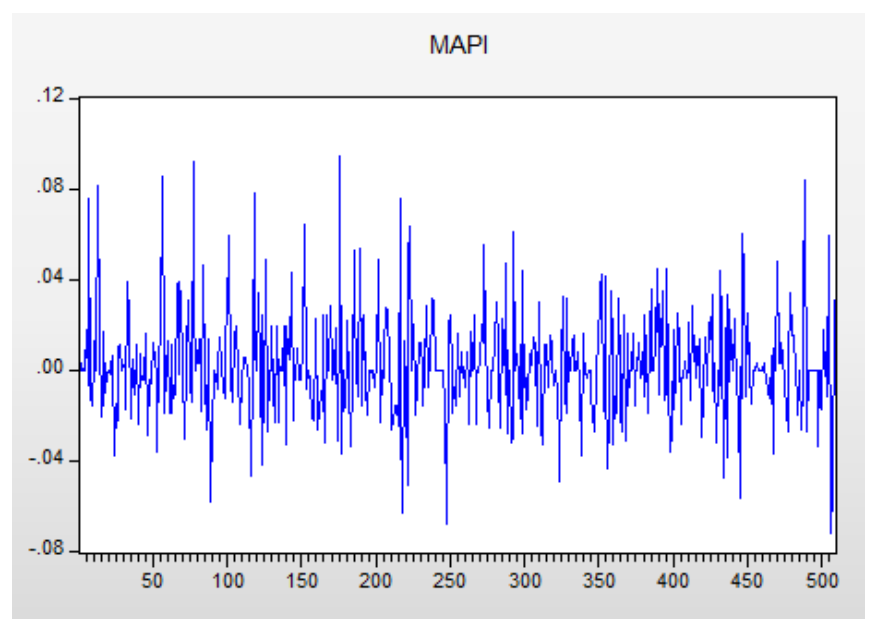

b. Grafik Perkembangan Return Saham MAPI

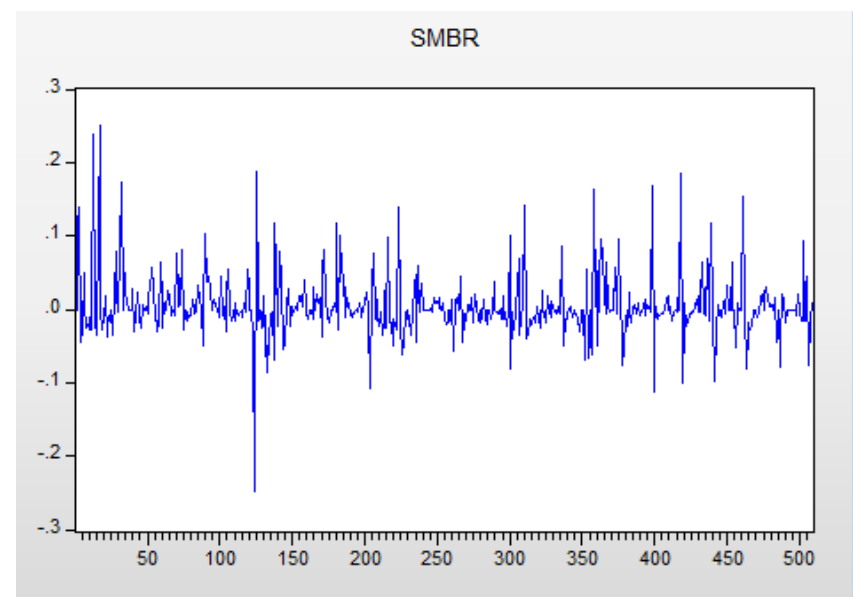

d. Grafik Perkembangan Return Saham SMBR

Gambar 1. Grafik Perkembangan Return Saham INAF, MAPI, WICO dan SMBR.

\section{Pembentukan Portofolio Optimal Model MAD}

Pembentukan portofolio optimal model MAD dilakukan melalui langkah-langkah berikut ini:

\section{a. Menghitung nilai expected return}

Nilai expected return saham INAF, MAPI, SMBR dan WICO diukur dengan menggunakan rata-rata geometri (Geometri Mean). Hasilnya ditampilkan pada Tabel 1.

Tabel 1. Expected return saham INAF, MAPI, SMBR dan WICO.

\begin{tabular}{ccccc}
\hline & INAF & MAPI & SMBR & WICO \\
\hline Expected return & 0.001943095 & 0.001372664 & 0.003364382 & 0.004468309 \\
\hline
\end{tabular}

\section{b. Menghitung nilai return minimal}

Return minimal yang diinginkan investor adalah nilai mean dari expected return seluruh saham. Perhitungan return minimal adalah:

$$
\begin{aligned}
R & =\frac{0,001943095+0,001372664+0,003364382+0,004468309}{4} \\
& =0,002787112
\end{aligned}
$$

Sehingga kendala pertama pembentukan portofolio MAD menjadi:

$$
0,001943095 w_{1}+0,001372664 w_{2}+0,003364382 w_{3}+0,004468309 w_{4} \geq 0,002787112
$$




\section{c. Menghitung nilai MAD masing-masing saham}

Garis besar perhitungan nilai MAD masing-masing saham adalah nilai mutlak simpangan terhadap nilai realized return dan expected return sebagai pengukuran risiko setiap periode, kemudian dicari nilai rata-ratanya. Hasilnya disajikan pada tabel 2.

Tabel 2. Nilai MAD untuk saham INAF, MAPI, SMBR dan WICO.

\begin{tabular}{ccccc}
\hline & INAF & MAPI & SMBR & WICO \\
\hline$M A D$ & 0.029534427 & 0.016645548 & 0.025416145 & 0.029706896 \\
\hline
\end{tabular}

Nilai MAD masing-masing saham digunakan sebagai koefisien fungsi tujuan model MAD. Sehingga fungsi tujuan tersebut menjadi:

$$
f(w)=0,029534427 w_{1}+0,016645548 w_{2}+0,025416145 w_{3}+0,0297069896 w_{4}
$$

\section{d. Menghitung bobot investasi}

Setelah semua nilai yang diperlukan pada metode MAD diketahui maka langkah selanjutnya adalah mencari bobot investasi pada masing-masing saham. Bobot portofolio optimal model MAD diperoleh dengan menyelesaikan masalah optimasi berikut ini:

Fungsi $\quad f(w)=0,029534427 w_{1}+0,016645548 w_{2}+0,025416145 w_{3}+0,0297069896 w_{4}$ tujuan:

Kendala: $\quad 0,00194309 w_{1}+0,00137266 w_{2}+0,00336438 w_{3}+0,00446831 w_{4} \geq 0,00278711$

$$
\begin{aligned}
& w_{1}+w_{2}+w_{3}+w_{4}=1 \\
& w_{i} \leq 0,40 ; i=1,2,3,4
\end{aligned}
$$

Pada kasus ini, batasan dana maksimal masing-masing saham sebesar $40 \%$. Hal ini dimaksudkan untuk menghindari kerugian yang besar jika saham tersebut mengalami kerugian.

Bobot portofolio optimal model MAD dapat dicari dengan menggunakan metode Simplex [12]. Hasil perhitungannya ditampilkan pada tabel berikut ini:

Tabel 3. Bobot Portofolio optimal model MAD.

\begin{tabular}{cc}
\hline Saham & Bobot \\
\hline INAF & 0,0005 \\
MAPI & 0,4000 \\
SMBR & 0,4000 \\
WICO & 0,1995 \\
\hline
\end{tabular}

Pada portofolio model MAD diperoleh pembentukan optimalnya terjadi dengan bobot pada masingmasing saham sebesar 0,05\% saham INAF, 40\% saham MAPI, 40\% saham SMBR dan 19,95\% saham WICO.

\section{e. Risiko dan return portofolio metode MAD}

Setelah nilai bobot investasi masing-masing saham diketahui, langkah selanjutnya adalah menghitung nilai return portofolio dan risiko portofolio. Portofolio model MAD menghasilkan return portofolio sebesar $0,28 \%$ dan risiko portofolio sebesar $3,64 \%$.

\section{Pembentukan Portofolio Optimal Model CMV}

Pembentukan portofolio model Conditional Mean Variance dilakukan melalui langkah-langkah berikut ini:

\section{a. Uji stationer data return.}

Uji data stasioner return dilakukan dengan menggunakan uji akar unit. Hasil uji stasioner data return keempat saham disajikan pada gambar di bawah ini. 


\begin{tabular}{lccc}
\hline \hline & t-Statistic & Prob. \\
\hline \hline Augmented Dickey-Fuller test statistic & -20.92227 & 0.0000 \\
\hline Test critical values: $\quad 1 \%$ level & -3.443021 & \\
& $5 \%$ level & -2.867021 & \\
& $10 \%$ level & -2.569751 & \\
\end{tabular}

a. Hasil Uji akar unit INAF

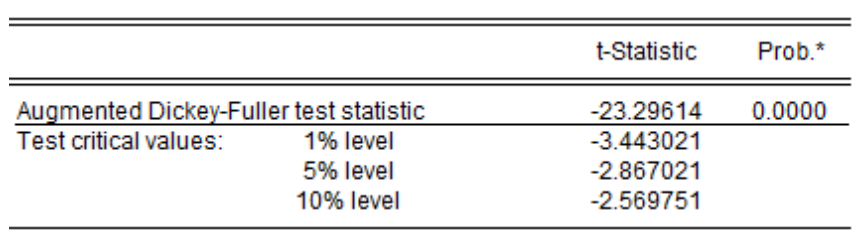

c. Hasil Uji akar unit SMBR

\begin{tabular}{lccc}
\hline \hline & & & \\
& & t-Statistic & Prob. ${ }^{*}$ \\
\hline \hline Augmented Dickey-Fuller test statistic & -18.25015 & 0.0000 \\
\hline Test critical values: & 1\% level & -3.443046 & \\
& $5 \%$ level & -2.867032 & \\
& $10 \%$ level & -2.569757 & \\
\hline \hline
\end{tabular}

b. Hasil Uji akar unit MAPI

\begin{tabular}{|c|c|c|c|}
\hline & & t-Statistic & Prob. ${ }^{*}$ \\
\hline Augmented Dicke & test statistic & -21.12523 & 0.0000 \\
\hline Test critical values & $\begin{array}{c}1 \% \text { level } \\
5 \% \text { level }\end{array}$ & $\begin{array}{l}-3.443021 \\
-2.867021 \\
-2569751\end{array}$ & \\
\hline
\end{tabular}

d. Hasil Uji akar unit WICO

Gambar 2. Hasil Statisioner Data Return Saham INAF, MAPI, SMBR dan WICO.

Pada Gambar 2, hasil uji akar terhadap keempat saham menunjukan nilai probabilitas sebesar 0,0000 . Dengan tingkat kepercayaan sebesar $95 \%$ kesimpulannya HO ditolak artinya artinya keempat saham sudah stasioner (karena prob $<0,05$ ).

\section{b. Uji Normalitas Data}

Setelah data sudah stasioner maka langkah selanjutnya adalah melakukan uji normalitas data. Alat uji yang digunakan untuk mengetahui data berdistribusi normal adalah uji Jarque-Bera. Hasilnya disajikan pada tabel berikut ini:

Tabel 4. Uji Jarque-Bera saham INAF, MAPI, SMBR dan WICO.

\begin{tabular}{ccccc}
\hline & INAF & MAPI & SMBR & WICO \\
\hline Jarque-Bera & 1423,822 & 114,4514 & 1709,438 & 3188,451 \\
Probability & 0,000 & 0,0000 & 0,0000 & 0,0000 \\
\hline
\end{tabular}

Pada Tabel 4 terlihat bahwa nilai probability untuk keempat saham sebesar 0,0000. Dengan tingkat kepercayaan sebesar 95\% dapat disimpulkan bahwa data tidak berdistribusi normal. Karena data return berdistribusi tidak normal maka $\alpha$ yang digunakan untuk menghitung value at risk harus dikoreksi terlebih dahulu dengan menggunakan Cornish Fisher Espansion. Nilai $\alpha^{\prime}$ hasil perhitungan dengan Cornish Fisher Espansion untuk return saham INAFsebesar 1,27427; saham MAPI sebesar 1,4979; saham SMBR sebesar 1,27641 dan saham WICO sebesar 0,99425.

\section{c. Estimasi model AR}

Estimasi model AR dilakukan dengan menggunakan persamaan (4). Hasil perhitungan model AR untuk masing-masing saham adalah:

$$
\begin{gathered}
r_{(\text {inaf }) t}=0,07427 r_{(\text {inaf }) t-1} \\
r_{(\text {mapi }) t}=-0,101218 r_{(\text {mapi }) t-2} \\
r_{(\text {smbr }) t}=0,084644 r_{(\text {smbr }) t-4} \\
r_{(\text {wico }) t}=0,071945 r_{(\text {wico }) t-1}
\end{gathered}
$$

Selanjutnya return masing-masing saham diestimasi menggunakan persamaan (4), kemudian dihitung mean atau rata-rata keempat saham. Hasilnya disajikan pada tabel di bawah ini:

Tabel 5. Rata-rata return saham INAF, MAPI, SMBR dan WICO dengan model AR.

\begin{tabular}{ccccc}
\hline & INAF & MAPI & SMBR & WICO \\
\hline Rata-rata return & 0,003209 & $-0,0000004$ & 0,000038 & 0,005926 \\
\hline
\end{tabular}




\section{d. Uji efek ARCH.}

Pada tahap ini akan dilakukan uji adanya efek heteroskedastiditas untuk keempat saham. Alat uji yang digunakan untuk mengetahui ada efek heteroskedastisitas dilakukan dengan uji ARCH-LM. Hasilnya disajikan pada tabel 6.

Tabel 6. Uji ARCH-LM saham INAF, MAPI, SMBR dan WICO dengan model AR.

\begin{tabular}{ccccc}
\hline & INAF & MAPI & SMBR & WICO \\
\hline F-statistic & 4,7641 & 2,7190 & 17,8143 & 22,6647 \\
Probability & 0,0295 & 0,0998 & 0,0000 & 0,0000 \\
\hline
\end{tabular}

Pada tabel 6 terlihat bahwa nilai probability saham INAP, SMBR dan WICO kurang dari 0,05. Artinya pada tingkat kepercayaan sebesar 95\% return keempat saham terdapat heteroskedastisitas (ARCH). Sedangkan pada saham MAPI, nilai probability sebesar 0,0998. Artinya dengan tingkat kepercayaan sebesar $90 \%$, return saham MAPI mengandung efek heteroskedastisitas.

\section{e. Estimasi model GARCH}

Setelah hasil uji efek ARCH membuktikan ada heteroskedastisitas dalam data, maka langkah selanjutnya mengestimasi model GARCH. Pemodelan GARCH digunakan untuk mengsetimasi variansi return keempat saham.

Estimasi model GARCH dilakukan dengan menggunakan persamaan (5). Hasil perhitungan model GARCH untuk masing-masing saham adalah:

$$
\begin{aligned}
& \sigma_{(\text {inaf }) t}^{2}=0,001145+0,324899 \varepsilon_{t-1}^{2}+0,311463 \sigma_{(\text {inaf }) t-1}^{2} \\
& \sigma_{(\text {mapi }) t}^{2}=0,000322+0,117547 \varepsilon_{t-1}^{2}+0,30544 \sigma_{(\text {mapi }) t-1}^{2} \\
& \sigma_{(\text {smbr }) t}^{2}=0,000930+0,448870 \varepsilon_{t-1}^{2}+0,254918 \sigma_{(\text {sbmr }) t-1}^{2} \\
& \sigma_{(\text {wico }) t}^{2}=0,000497+0,298944 \varepsilon_{t-1}^{2}+0,58560 \sigma_{(\text {wico }) t-1}^{2}
\end{aligned}
$$

Setelah diperoleh model GARCH kemudian diestimasi variansi setiap saham dengan model tersebut. Selanjutnya, dihitung rata-rata variansi keempat saham, hasilnya ditampilkan pada tabel berikut ini

Tabel 7. Rata-rata variansi return saham INAF, MAPI, SMBR dan WICO dengan model GARCH.

\begin{tabular}{ccccc}
\hline & INAF & MAPI & SMBR & WICO \\
\hline Rata-rata variansi & 0,002697 & 0,001963 & 0,00600 & 0,002178 \\
\hline
\end{tabular}

\section{f. Bobot portofolio optimal model GARCH}

Pembentukan portofolio optimal model CMV dilakukan dengan menggunakan conditional mean dan conditional variance yang diperoleh dari perhitung AR dan $\mathrm{GARCH}$. Pada kasus ini, dipilih return portofolio yang diharapkan sebesar $0,1 \%$, maka dengan menggunakan persamaan (6). Hasil perhitungan portofolio model CMV ditampilkan pada tabel berikut ini:

Tabel 8. Bobot Portofolio optimal model MAD.

\begin{tabular}{cc}
\hline Saham & Bobot \\
\hline INAF & 0,1706 \\
MAPI & 0,0893 \\
SMBR & 0,6679 \\
WICO & 0,0720 \\
\hline
\end{tabular}

Pada saat investor menginginkan return portofolio sebesar $0,1 \%$, maka bobot masing-masing saham yang diperoleh yaitu INAF sebesar 17,06\%, MAPI sebesar 8,93\%, SMBR sebesar $66,79 \%$ dan WICO sebesar $7,2 \%$. Dari pembentukan portofolio ini diperoleh risiko portofolio sebesar $0,001173 \%$. 


\section{Perbandingan Kinerja Portofolio Model MAD dan CMV}

Hasil perhitungan kedua model memberikan hasil yang berbeda beda. Portofolio model MAD menghasilkan return portofolio sebesar $0,28 \%$ dan risiko portofolio sebesar 3,64\%. Sedangkan, portofolio model CVM menghasilkan menghasilkan return portofolio sebesar $0,10 \%$ dan risiko portofolio sebesar $0,001 \%$.

Pada penelitian ini, kinerja kedua portofolio dilakukan dengan menggunakan indeks Sortino [1], [11]. Indeks Sortino menghitung menghitung excess return portofolio dari Minimum Acceptable Return $(M A R)$ untuk setiap downside deviation $\left(\sigma_{\text {down }}\right)$.

Namun karena penelitian ini dilakukan terhadap saham secara umum maka tingkat suku bunga Sertifikat Bank Indonesia digunakan sebagai MAR. Rata-rata tingkat suku bunga harian Sertifikat Bank Indonesia $\left(\bar{R}_{f}\right)$ periode 4 Juli 2016 sampai dengan 4 Juli 2018 yaitu 0,16\%. Hasil perhitungan indeks Sortino dari portofolio model MAD dan model CMV.

Tabel 9. Indeks Sortino untuk portofolio model MAD dan CMV.

\begin{tabular}{llll}
\hline Portofolio & $\sigma_{\text {down }}$ & $\bar{R}_{p}-\bar{R}_{f}$ & Indeks Sortino \\
\hline MAD & 0,013248963 & 0,00197957 & 0,1494 \\
CMV & 0,0000008 & 0,0084284 & 10,532 \\
\hline
\end{tabular}

Pada tabel terlihat bahwa kinerja portofolio CMV dengan return portofolio 0,001 yang lebih baik dibanding dengan portofolio MAD dan CMV dengan return portofolio yang lain, karena memiliki nilai Sortino lebih besar.

\section{Kesimpulan}

Portofolio model Mean Absolute Deviation (MAD) dan Conditonal Mean Variance (CMV) adalah portofolio yang dikembangkan dari portofolio Mean Variance yang diperkenalkan pertama kali oleh Markowitz.

Portofolio model MAD mengukur risiko portofolio dengan menggunakan rata-rata nilai mutlak penyimpangan (Mean Absolute Deviation), sehingga portofolio optimal model MAD dapat diselesaikan dengan metode pemrograman linear. Sedangkan, portofolio model CMV mengatasi kelemahan dari portofolio model MV dimana diasumsikan data tidak boleh terjadi autokorelasi.

Hasil studi empiris pada data saham yang terdaftar di ISSI, diperoleh portofolio optimal model MAD adalah sebesar 0,05\% saham INAF, 40\% saham MAPI, 40\% saham SMBR dan 19,95\% saham WICO. Sedangkan portofolio optimal model CMV terbentuk bobot saham INAF sebesar 17,06\%, MAPI sebesar $8,93 \%$, SMBR sebesar $66,79 \%$ dan WICO sebesar 7,2\%. Selanjutnya pada kasus ini, hasil analisis kinerja portofolio dengan menggunakan indeks Sortino menunjukan bahwa kinerja portofolio model CMV lebih baik dibandingkan model portofolio MAD.

\section{Referensi}

[1] Ashraf Chaudhry, Helen L. Johnson. 2008. The Efficacy of the Sortino Ratio and Other Benchmarked Performance Measures under Skewed Return Distributions. Australian Journal of Management, Vol. 32 (3).

[2] Dedi Rosadi. 2006. Pengantar Analisa Runtun Waktu. Yogyakarta: FMIPA Universitas Gajah Mada.

[3] Hanene Salah, Ali Gannoun, Mathieu Ribatet. 2016. Conditional Mean-Variance and Mean-Semivariance models in portfolio optimization. Quantitative Finance. HAL Id: hal-01404752.

[4] Holt, M. T., and S. V. Aradhyula. 1989. Price Risk in Supply Equations: An Application of GARCH Time-Series Models to the U.S. Broiler Market. Proceedings of the NCR-134 Conference on Applied Commodity Price Analysis, Forecasting, and Market Risk Management. Chicago, IL.

[5] Husnan, S.. 2008. Manajemen Keuangan Teori dan Penerapannya. Yogyakarta: BPFE.

[6] Jogiyanto. 2000. Teori Portofolio dan Analisis Investasi. 2nd edition. Yogyakarta: BPFE.

[7] Konno, H., Yamazaki, H. 1991. Mean-absolute deviation portfolio optimization model and its applications to Tokyo stock market. Management Science. Vol 37(5), pp 519531.

[8] Markowitz, H. 1952. Portfolio selection. The Journal of Finance. Vol 7(1), pp 7791. 
[9] Pegah Kolbadi, Hamed Ahmadinia. 2011. Examining Sharp, Sortino and Sterling Ratios in Portfolio Management, Evidence from Tehran Stock Exchange. International Journal of Business and Management. Vol 6 (4). Pp: 222236.

[10] Satheesh V. Aradhyula and Matthew T. HoltG. 1988. GARCH Time-Series Models: An Application to Retail Livestock Prices. CARD Working Papers. 77. lowa State University

[11] Sortino F, Van der Meer R. 1991. Downside risk, Journal of Portfolio Management. Vol 17 (2), pp 2731.

[12] Wirdasari, D., 2009. Metode Simpleks dalam Program Linier. SA/NTIKOM, 6(1), pp. 276-285. 